\title{
Analysis of Design Applications In Public Street Furniture In Bandung
}

\author{
I Rachmayanti ${ }^{1}$, G Hartanti ${ }^{2}$, B Setiawan ${ }^{3}$, A P Fernando ${ }^{4}$ \\ Interior Design Program, Bina Nusantara University, Jakarta, Indonesia \\ ${ }^{1}$ ikarachmayanti@binus.ac.id, ${ }^{2}$ ghartanti@binus.edu, ${ }^{3}$ bsetiawan@binus.edu, \\ 4aldofernando@hotmail.co.id
}

\begin{abstract}
As one of UNESCO Design City, Bandung is committed to develop its designbased public facilities and creativity, including revamping of city parks, arrangement of sidewalks and other public facilities. Street furniture theme is taken as research material, based by existence as one of the main tools in public space and facilities which become an important indicator public space quality of the city. Therefore it is necessary to have an appropriate analysis of the street furniture application and integrated in accordance with its capacity as a world design city. This research will examine the existence of street furniture at Bandung strategic points in its context as City of Design, by taking Visual Research method. It is expected that this research can be the initial input for the establishment of a guidelines for other cities in Indonesia to create cities that are design friendly, using sustainable materials and comfortable for its users.
\end{abstract}

Keywords: Bandung City, Street Furniture, Public Space

\section{INTRODUCTION}

The development of Bandung in the field of creative economy and design is very rapid in the last 10 years, marked by a government intention to create Bandung as a creative city that can be an example of other cities in Indonesia which would also be a progress for the overall development of Indonesia [1]. This intention is indicated by the establishment of creative economy support forums such as Bandung Creative City Forum which accommodate creative communities and actively develop branding strategies as well as creative activities both in the form of events and community events, as well as physical nature in the form of development of creative and design-based public facilities. Awarded as a City of Design by UNESCO in 2015, Bandung is committed to developing its design-based public facilities and creativity. Street furniture theme is taken as research material is based by existence as one of the main tools in public space and municipal facilities which become an important indicator factor of the quality of its city public space. Therefore it is necessary for the analysis of the appropriate application of street furniture and integrated in accordance with the capacity of the city as a world design city. 


\section{METHOD}

This study analyzes the variables related to Bandung criteria as one of the world design cities. The steps of data collection to be performed are as follows:

1. Primary data collection from books, journals, articles and other references related to the field of urban science, street furniture and townscape. It is expected to get an idea of the strategic points ofcreative and design development in the city public area so that the research team can begin to collect the primary data of the second stage.

2. From the data collection, the analysis will use Visual Environment Research method [2], which is a method of research and planning that emphasizes the visual aspects of urban public environment. In the mapping of criteria and characteristics of the design city will be analyzed what factors become the determinants and how the application of the design on the street furniture in the public area.

\section{RESULT AND DISCUSSION}

\subsection{Creative City}

This concept was published by Landry and Bianchini [3] in "The Creative City".This creative city concept emerged as an alternative solution to urban problems in terms of design and creativity that is faced by big cities in the world. The challenge is not to replace the whole ideology of thought in that direction but how to combine new thinking with existing ones into a new paradigm in the arrangement of cities. According to and Bianchini [3], there are several steps that can be used as guidance to develop an innovation-based creative environment such as reshaping the city, presenting urban cosmetics and theatrical illusions, themarriage of old and new, creating genius loci.

\subsection{Street Furniture}

\subsubsection{Definition}

According to [4], street furniture includes physical elements in urban landscape such as: telephone booths, garden and street lights, lawn chairs, cribs, road signs, CCTV cameras, roadblocks, building barriers, railings, parks, fountains, bus stops, statues, and monuments. In its contribution to the establishment of the identity of the city, the quality and setting of street furniture location in urban public space becomes a marker of urban space quality [4]

\subsubsection{Main Criteria in Street Furniture Placement}

Some criteria to consider in designing quality street furniture [5] :

- Placement of street furniture, should be based on its function, and relate to the character ofthe area where the object is located. Objects should be spread evenly on the area according to their respective functions.

- Design based on security, the construction used should use a safe material and is designed toprevent injury to its users by avoiding sharp corners and protruding bolts. Type of street furniture and its laying should consider the visibility, lighting and user friendly. 
- Materials and colors, the ideal design is that considering the strength, simple shape, localmaterial, sustainable materials and in neutral colors or natural shades with bright color accents.

\subsection{Bandung City Street Furniture}

Street furniture element chosen as research object is seating facility that becomes important element in the town's streetscapes, it designed not only to be functional but it also has to support city beautification. This research will analyzed the seating facility on three locations which are also categorized in three subjects to define its elements in terms of design, function and its congruity to its environment.

\subsubsection{Street}

This research is selected Asia Afrika street and Diponegoro street (in front of Gedung Sate), as both of streets has their historical value and some of the busiest and iconic street in Bandung.

\section{a. Asia Afrika}
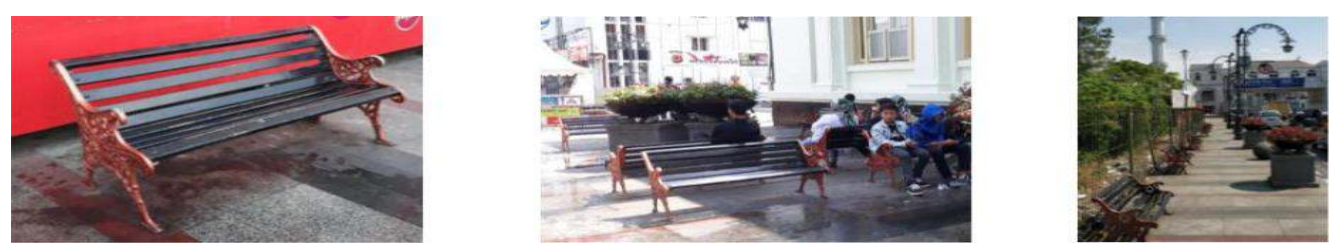

Figure 1. Asia Afrika Street - Seating facility.

Table 1. Asia Afrika Street - Seating facility study.

\begin{tabular}{|c|c|c|}
\hline $\begin{array}{l}\text { STREET FURNITURE } \\
\text { LOCATION }\end{array}$ & $\begin{array}{c}\text { SECURITY BASED } \\
\text { DESIGN }\end{array}$ & $\begin{array}{l}\text { MATERIAL \& } \\
\text { COLORS }\end{array}$ \\
\hline $\begin{array}{l}\text { a. There are plenty of lawn } \\
\text { chairs and the layout is well } \\
\text { arranged }\end{array}$ & $\begin{array}{l}\text { a. Garden chairs are quite } \\
\text { ergonomic in terms of } \\
\text { shape and size. }\end{array}$ & $\begin{array}{l}\text { Material : Metal Plate } \\
\text { Unfinished }+ \text { cement } \\
\text { aggregate concrete }+ \\
\text { grass }\end{array}$ \\
\hline $\begin{array}{l}\text { b. During the day there are } \\
\text { some seats that are protected } \\
\text { from the heat of the sun as it } \\
\text { is covered in trees and } \\
\text { buildings, but there are some } \\
\text { who do not. }\end{array}$ & $\begin{array}{l}\text { b. Equipped with a } \\
\text { backrest and handrest } \\
\text { for user convenience }\end{array}$ & $\begin{array}{l}\text { color: Natural } \\
\text { Unfinished }\end{array}$ \\
\hline $\begin{array}{l}\text { c. Visitors and park chair users } \\
\text { are crowded because of the } \\
\text { location that is in the center } \\
\text { of the city, but visible space } \\
\text { and circulation is still good }\end{array}$ & & \\
\hline
\end{tabular}


d. There is only 1 common garden chair on $\mathrm{Jl}$ Asia Afrika, which is common in some areas in Bandung

\section{b. Diponegoro (in front of Gedung Sate)}

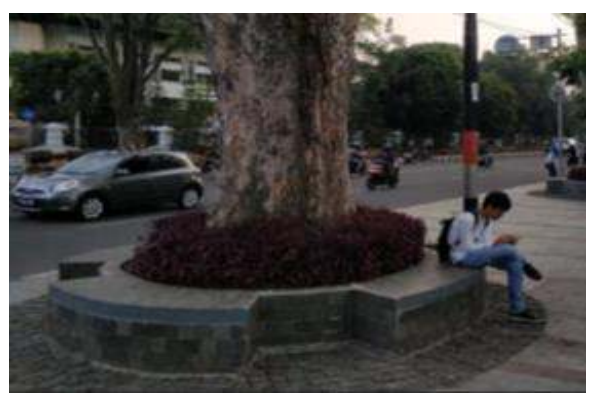

Figure 2. Diponegoro Street - Seating facility.

Table 2. Diponegoro Street - Seating facility study.

\begin{tabular}{|c|c|c|}
\hline STREET FURNITURE LOCATION & $\begin{array}{l}\text { SECURITYBASED } \\
\text { DESIGN }\end{array}$ & $\begin{array}{l}\text { MATERIAL } \\
\text { \& COLORS }\end{array}$ \\
\hline $\begin{array}{l}\text { a. This garden chair also serves as a } \\
\text { box of plants. Surrounds every big } \\
\text { tree with good shade. }\end{array}$ & $\begin{array}{l}\text { Garden chairs are } \\
\text { functional. Just to sit with } \\
\text { no backrest and handrest. }\end{array}$ & $\begin{array}{l}\text { - Material : cement } \\
\text { aggregate } \\
\text { concrete }\end{array}$ \\
\hline $\begin{array}{l}\text { b. This garden chair is protected from } \\
\text { the heat of the sun because it is } \\
\text { under a shady tree. }\end{array}$ & & $\begin{array}{l}\text { - Color : Natural } \\
\text { Unfinished }\end{array}$ \\
\hline $\begin{array}{l}\text { c. As an outdoor feature, it will be } \\
\text { wet when it is rain to its function } \\
\text { as a planter box, it creates spacious } \\
\text { ambiance and has a good distance } \\
\text { to each tree. }\end{array}$ & & \\
\hline $\begin{array}{l}\text { d. Only } 1 \text { type of chair particularly in } \\
\text { this area }\end{array}$ & & \\
\hline
\end{tabular}

\subsubsection{Communal Space}

This research is selected Alun-alun Bandung and Alun-alun Cicendo, which are becomes Bandung landmarks and city communal space. Many creative and art event held in these area that they became government concerns and focused to beautify these communal spaces. 


\section{a. Alun-alun Bandung}
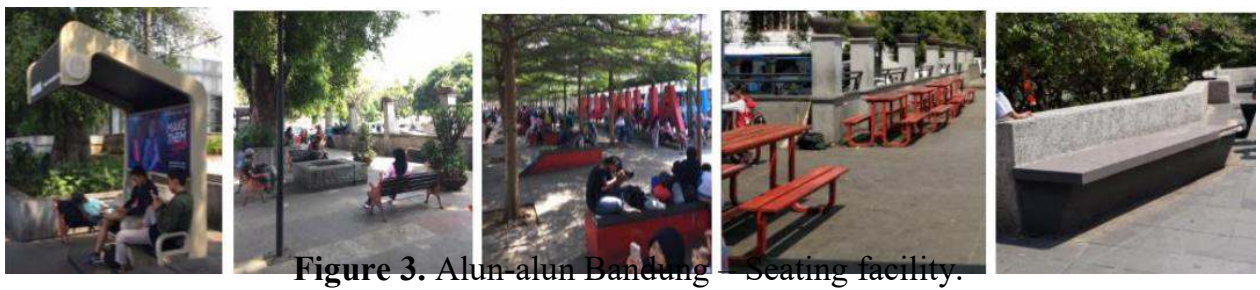

Table 3. Alun-alun Bandung - Seating facility study.

\section{LOCATION \\ a. Its layout is well planned}

STREET FURNITURE

b. During daytime, the chairs are protected under shady trees.

c. Visitors are crowded because of the strategic location that is in the center of the city but visible space and circulation is still good

d. some design variety with loose and built-in furniture

e. its various with new design based on the park theme and also a few that has general design as other public space in Bandung

\section{MATERIAL \&} COLORS

Seating arrangement 1 chairs resemble bus stops. There is already a cover on the top and a hand rail for safety and comfort, it is a new design which is equipped with USB power outlet facility

Seating arrangement 2 is a general chair that is found in public areas in Bandung it has an ergonomic size and a strong structure

Seating arrangement 3 put forward aesthetics rather than security, its slope does not functioned well, In addition the seat height is higher than the size of the standard seat, making it less ergonomic

Seating arrangement 4 has a sharp corner angle that is not secure and comfortable to sit on

Seating arrangement 5 has a standard size. Functional but lacking in aesthetic terms
Chair 1 : mixed material with steel plate and cement cast, white and cream paint finish

Chair 2 : cast iron material for its structure and wood planks as seating base and backrest

Chair $3:$ mixed material with red stained cement and dark grey ceramic

Chair 4 : cast concrete with natural unfinished color Chair 5 : cast iron material in red color for its structure and wood planks as seating base and backrest 


\section{b. Alun-alun Cicendo}
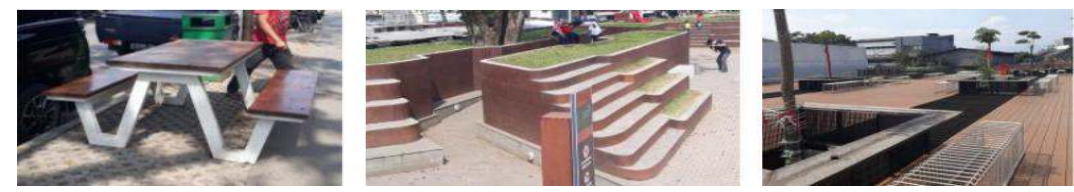

Figure 4.Alun-alun Cicendo- Seating facility.

Table 4. Alun-alun Cicendo - Seating facility study.

\begin{tabular}{cc}
\hline STREET FURNITURE & SECURITY BASED \\
LOCATION & DESIGN \\
\hline
\end{tabular}

a. Its layout is well planned

The chair is quite exposed Seating arrangement $1:$ the to the heat at daytime because the greenery surrounding has not grown yet

b. since this place is quite exposed especially at noon, there are few people come at daytime

c. It quite spacious so it has good circulation and activity space some design variety with loose and built-in furniture

d. Its various with new design based on the park theme and also a few that has general design as other public space in Bandung

\section{MATERIAL \& COLORS}

according to its material, all of the seating arrangement in this area is quite hot during day time series of tables and chairs has an ergonomic size and a strong structure

chair 1 : wooden material, with white and brown color stain

Seating arrangement 2 : it has multifunction arrangement as planters so it designed with gradual layers but this make the design less secure for kids

chair 2 : Metal Plate Unfinished + cement aggregate concrete + grass, color natural unfinished

Seating arrangement 3 : design 1 - as planters at the bottom and seating space on diameter, white duco finishing top

Design 2 - common seating with steel slate, both has rigid structure and good ergonomics

chair 4 : cement cast material for seat base, bottom construction is metal plate

\subsubsection{Public Park}

This research is selected Lansia Park (Taman Lansia) as the main research object for this category due to its size that quite big and can be considered as main public park since it has a lot of other facilities such as toilet, musholla and kids play area. 

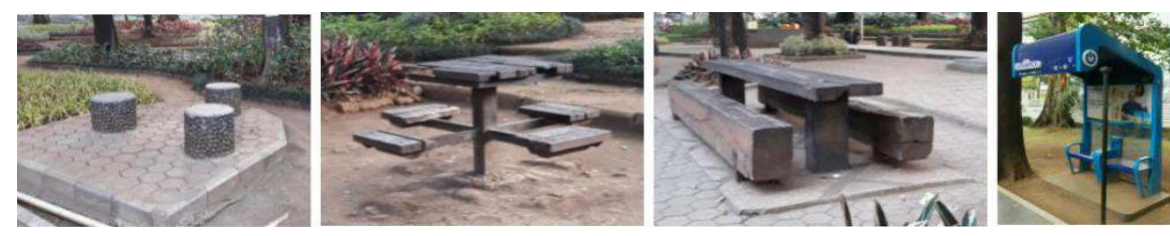

Figure 5. Public Park - Seating Facility.

Table 5. Lansia Park - Seating Facility Study.

\begin{tabular}{|c|c|c|c|}
\hline & $\begin{array}{c}\text { STREET FURNITURE } \\
\text { LOCATION }\end{array}$ & $\begin{array}{c}\text { SECURITY BASED } \\
\text { DESIGN }\end{array}$ & MATERIAL \& COLORS \\
\hline a. & $\begin{array}{l}\text { There are many chairs and the } \\
\text { layout is well organized }\end{array}$ & $\begin{array}{l}\text { Chair } 1 \text { is very functional, } \\
\text { bench type. }\end{array}$ & $\begin{array}{l}\text { Chair } 1: \text { natural color } \\
\text { cast cement with stone } \\
\text { decoration }\end{array}$ \\
\hline b. & $\begin{array}{l}\text { During the day most of the } \\
\text { seats are protected from the } \\
\text { heat of the sun because it is } \\
\text { covered by lush trees, and } \\
\text { some are not }\end{array}$ & $\begin{array}{l}\text { Chair } 2 \text { is a seating and } \\
\text { table group arrangement, in } \\
\text { bad condition and dirty, so } \\
\text { it does not have secure } \\
\text { element }\end{array}$ & $\begin{array}{l}\text { Chair } 2 \text { : mixed material } \\
\text { with wood and steel } \\
\text { structure painted black }\end{array}$ \\
\hline c. & $\begin{array}{l}\text { Visitors are quite crowded } \\
\text { because the location is in } \\
\text { front of the infamous Gedung } \\
\text { Sate, but it has good } \\
\text { circulation and visible space }\end{array}$ & $\begin{array}{l}\text { Chair } 3 \text { is a seating and } \\
\text { table group arrangement, } \\
\text { with quite rigid structure } \\
\text { and less maintenance }\end{array}$ & $\begin{array}{l}\text { Chair } 3 \text { : natural stain } \\
\text { wooden material }\end{array}$ \\
\hline d. & $\begin{array}{l}\text { The chairs have a variety of } \\
\text { designs its various with new } \\
\text { design the park theme and } \\
\text { also a few that has based on } \\
\text { general design as other public } \\
\text { space in Bandung }\end{array}$ & $\begin{array}{l}\text { Chairs } 4 \text { resemble bus } \\
\text { stops. There is already a } \\
\text { cover on the top and a hand } \\
\text { rail for safety and comfort, } \\
\text { It is a new design which is } \\
\text { equipped with USB power } \\
\text { outlet facility }\end{array}$ & $\begin{array}{l}\text { Chair } 4: \text { mixed material } \\
\text { with cast cement and } \\
\text { solid steel, blue color } \\
\text { combination with letters }\end{array}$ \\
\hline
\end{tabular}

\section{CONCLUSION}

This study provides analysis of one of some important street element in Bandung, which is seating facilities. From the analysis above it can be seen that even though Bandung has various theme parks, iconic streetscapes and communal spaces, they does not have many variation on seating facility design. Some has their own thematic design following its location theme, but most of it is quite general with classic designed chair. This tendency shows that from street furniture design wise as it should be an outstanding design complimenting its location theme, it does not seen as one unity, especially in some area has a playful design but equipped with old school chair design that it does not really goes well with the overall design. Based on this conclusion, this study can be an early step for detailed evaluation of current design that can be used as guidance to improve Bandung street furniture design in future time, especially in creating more sustainable elements, therefore can support Bandung's title as Creative and Design City more than today. 


\section{REFERENCES}

[1] A. Rifai, N. Sulaksana, T. Y. W. M. Iskandarsyah, M. Sulastri, P. P. Raditya, and S. Mulyani, "Development of Urban Areas in Potential Areas of Natural Disasters in South Bandung, Indonesia," \{IOP\} Conf. Ser. Earth Environ. Sci., vol. 145, p. 12116, Apr. 2018.

[2] H. Sanoff, Visual Research Methods in Design. New York: Van Nostrand Reinhold, 1991.

[3] C. Landry and F. Bianchini, The Creative City. London, UK: Demos, 1995.

[4] M. Carmona, T. Heath, T. Oc, and S. Tiesdell, Public Places - Urban Space: The Dimensions of Urban Design, 2nd ed. Oxford, UK: Architectural Press, 2011.

[5] G. F. Yücel, "Street Furniture and Amenities: Designing the User-Oriented Urban Landscape," in Advances in Landscape Architecture, InTech, 2011. 